\title{
Assessment of large-scale wind resource features in Algeria
}

\author{
Sidi Mohammed Boudia ${ }^{\text {a, }}$, João Andrade Santos ${ }^{\text {b }}$ \\ ${ }^{a}$ Centre de Développement des Energies Renouvelables, CDER, 16340, Algiers, Algeria \\ ${ }^{\mathrm{b}}$ Physics Department, Centre for the Research and Technology of Agro-Environmental and Biological Sciences, CITAB, Universidade de Trás-os-Montes e Alto \\ Douro, UTAD, 5000-801, Vila Real, Portugal
}

\section{A R T I C L E I N F O}

\section{Article history:}

Received 13 July 2019

Received in revised form

16 September 2019

Accepted 5 October 2019

Available online 7 October 2019

\section{Keywords:}

Wind resource

Wind turbine

Energy production

ERA-Interim

Algeria

\begin{abstract}
A B S T R A C T
This study presents an assessment of the wind potential over the whole Algerian territory, based for the first time on a reanalysis dataset. Thereby, 33 years (1981-2014) of 6-hourly wind components from ERA-Interim reanalysis are used for assessing the wind energy large-scale features over the largest country in Africa. The ERA-Interim data are validated against observational wind speeds from 42 sites across Algeria by using the two-sample Kolmogorov-Smirnov and the Wilcoxon-Mann-Whitney tests, while the Generalized Extreme Value (GEV) theretical distribution is used to characterize wind speeds. Overall, the ERA-Interim dataset validation reveals good agreement with observations in the south and less near the coastline. The mean wind speed and prevailing wind direction are assessed on the annual, monthly and hourly timescales. Mean wind speeds ranging between $2.3 \mathrm{~m} \mathrm{~s}^{-1}$ in the North, and $5.3 \mathrm{~m} \mathrm{~s}^{-1}$ in the South are found. Furthermore, the windiest periods are the warmer months and during daytime over almost all of the country. The gridded wind energy outputs for a representative wind turbine $(850 \mathrm{~kW})$ are also assessed. These informations are of foremost relevance to decision-makers and to the energy production sector in Algeria, providing guidelines for new wind farms installations.
\end{abstract}

๑) 2019 Elsevier Ltd. All rights reserved.

\section{Introduction}

Since 2011, Algeria has made the promotion of renewable energies one of its main challenges for meeting the growing energy demands and to replace gradually the use of fossil fuels, which are currently the main resource for the national electric power generation $[1,2]$. For this purpose, an ambitious strategy for encouraging and developing renewable energy production is being implemented, where the wind energy constitutes the second axis of development, with an electricity production expected to reach about $5 \mathrm{GW}$ in 2030 [3]. However, for an efficient exploitation, it is critical to have accurate information on the potential wind resource at a given place before the installation of wind energy generators/ turbines. Thus, wind energy is regarded as one of the most important line of research within different scientific institutions in Algeria, where several studies on wind resource assessment have been carried out since 2000 , especially during the last ten years, at different regions over Algeria.

Aiming at establishing wind maps in Algeria, some studies were

\footnotetext{
* Corresponding author. Centre de Développement des Energies Renouvelables, CDER. BP. 62 Route de l'Observatoire Bouzaréah, 16340, Algiers, Algeria.

E-mail addresses: m.boudia@cder.dz, simmed1@yahoo.fr (S.M. Boudia).
}

conducted using data collected from meteorological masts at different temporal resolutions. In 2000, Merzouk [4] produced a wind atlas at the $10 \mathrm{~m}$ level, for which wind data taken every $3 \mathrm{~h}$ from 48 weather stations were used, covering almost all the topographic zones of the country. In 2011, Chellali et al. [5] updated the wind map of Algeria by performing a spectral analysis to study wind cycles, using daily mean wind speed collected by a network of 37 meteorological stations. Still using daily mean wind speed, the assessment of the Algerian wind resource was made by Boudia et al. [6], with data recorded over the last decade from 63 meteorological stations distributed all across the Algerian territory, plus 24 in neighboring countries close boundaries, so as to refine the tracing of the borders map. The latest study mapping the wind speed in Algeria was carried out in 2018 by Nedjari et al. [7], where hourly and 3-hourly data, mostly recorded between 2004 and 2014 from $>70$ new sites, were used to update the previous wind resource assessment. The wind potential in different Algerian regions has been revised by incorporating new weather stations, such as Mechria [6], Hassi R'mel [5] and In Salah [7], to cite only the most windy sites. Nevertheless, the data quality and spatial coverage of the Algerian Meteorological Office (ONM) network, with meteorological stations predominantly located in airports and primarily devoted to the aerospace market, clearly limits an accurate wind 
resource assessment throughout the country.

Therefore, alternative data sources must be explored to quantify the actual wind resources, by providing accurate estimates of the available wind power in Algeria, where there is a lack of highquality in situ datasets available over long time periods. For this purpose, reanalysis data, which commonly represent an assimilated form of land based meteorological stations, buoy, ship and satellite data $[8,9]$, with gridded wind data covering the whole target area over relatively long and uninterrupted time periods, is expected to provide a more accurate and spatially coherent representation of the large-scale wind resources, particularly in regions where no wind data measurements are available. This approach is particularly useful in such a large country as Algeria, with an area of almost 2.3 million $\mathrm{km}^{2}$. In fact, in Algeria, in situ surface data provided by meteorological measuring masts are generally concentrated in the north, along the coastline and in the highlands, while they are very sparse in the south, especially over the Sahara region, which indeed represents the largest part of the country. Furthermore, reanalysis data have been used to study wind resources in different regions in Europe, such as Northern Ireland [10], Great Britain [11], Germany [12] and Iberia [13,14], in addition to several offshore studies worldwide [15-17]. The reanalysis data can thereby be a good alternative to the more conventional wind speed analysis, based solely on weather station data.

A review of the literature demonstrates that a number of studies have been carried out using wind data provided by the ERA-Interim reanalysis dataset (European Centre for Medium-Range Weather Forecasts Re-Analysis Interim) [18], in different areas of the world. As an illustration, Mattar et al. [19] assessed the offshore wind power potential for the central coast of Chile. Nagababu et al. [20] evaluated the wind potential in six locations in India. Carvalho et al. [21] simulated the offshore wind energy resource over the Iberian Peninsula. Onea et al. [22] assessed the wind resource in the nearshore of the Mediterranean Sea. Overall, as also reported by Mattar et al. [23], the values delivered by ERA-Interim are a valid source of data for analyzing wind speed and direction, as well as offshore wind power, mostly in regions with low density weather station networks.

In the present study, the wind potential over the whole Algerian territory is assessed, using for the first time a reanalysis dataset (ERA-Interim), with 6-hourly wind data at the $10 \mathrm{~m}$ level and over the period of 1981-2014 (33 years). The first part of the study is devoted to the validation of the reanalysis wind data with in situ measurements. The second part of the study provides an assessment of the wind resource using the ERA-Interim dataset. The mapping of the diurnal variability in wind speed and prevailing wind direction over Algeria is also innovative. Lastly, the performance of a selected wind turbine of $850 \mathrm{~kW}$ rated capacity, specifically designed for electric power generation, is examined over the whole Algerian territory.

\section{Data and methods}

\subsection{Reanalysis data}

The ERA-Interim reanalysis database, generated by the European Centre for Medium-Range Weather Forecasts (ECMWF), is produced with a sequential data assimilation system [18,23], available from 1979 onwards [24]. This database counts 60 vertical levels, is provided on a regular grid with spatial resolution of $0.75^{\circ}$ latitude $\times 0.75^{\circ}$ longitude (roughly $70-80 \mathrm{~km}$ ) and with a time resolution of $6 \mathrm{~h}$ [25]. In the present study, the $10 \mathrm{~m}$ zonal and meridional wind components $(u, v)$ at $00,06,12$ and 18 UTC (4hourly data) are retrieved. The period covers 33 years of data, from 1 January 1981 to 31 December 2014, and over a geographical sector that covers the whole Algerian territory: $18-38^{\circ} \mathrm{N}$, $9.5^{\circ} \mathrm{W}-13^{\circ} \mathrm{E}$.

\subsection{Wind reanalysis}

In order to estimate the Algerian wind energy potential, the methodology shown in Fig. 1 is adopted. The zonal and meridional wind vector components $(u, v)$ at a height of $10 \mathrm{~m}$ above ground level (a.g.l.) were retrieved from ERA-Interim [26] and were used to

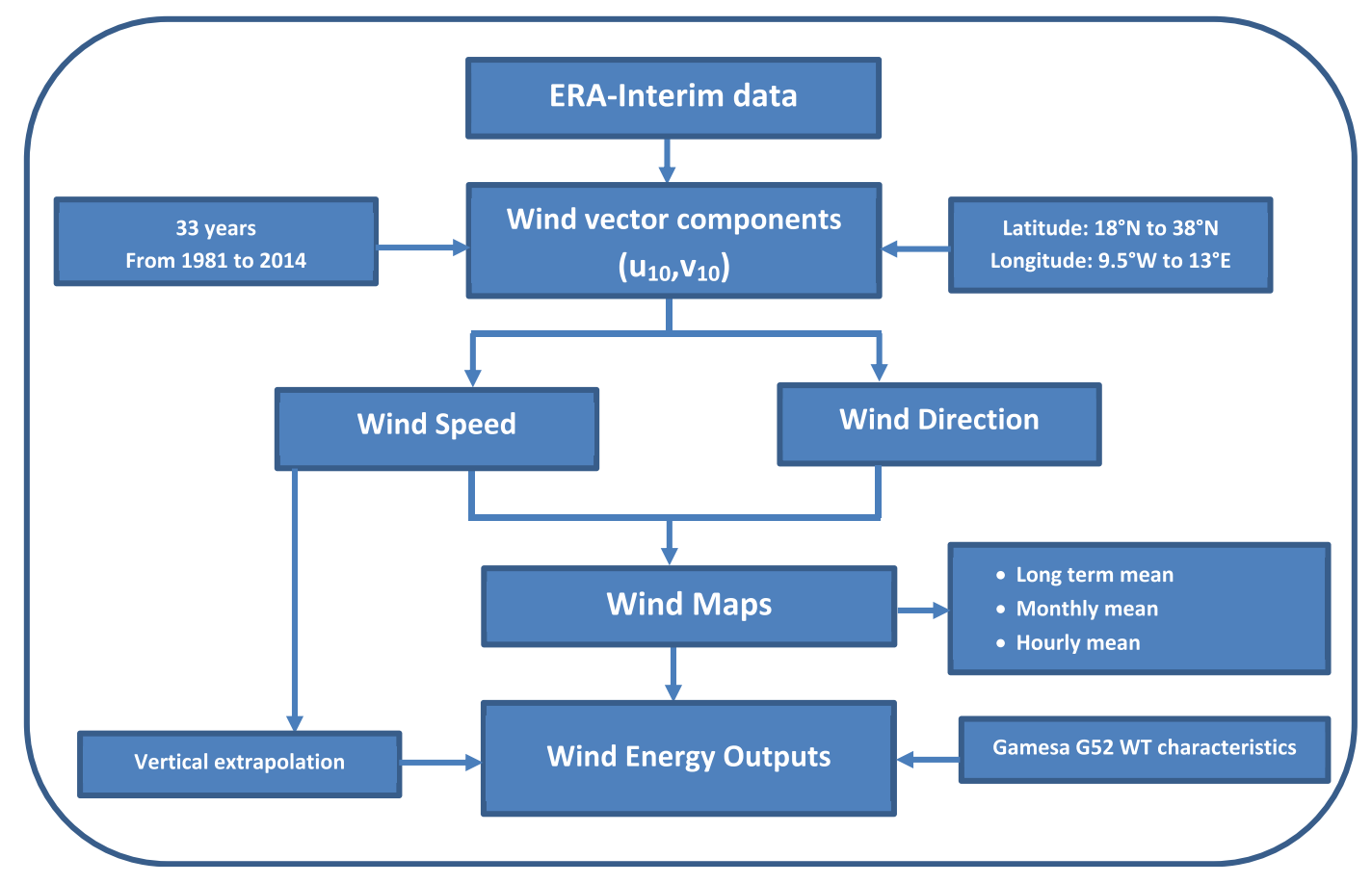

Fig. 1. Fluxogram of the methodology used to estimate the wind energy potential. 
compute both the wind speed $V$ and the wind direction $D$ for each gridpoint by using the following equations [27,28]:

$V=\sqrt{u^{2}+v^{2}}$

$D=\operatorname{tg}^{-1}(u, v) \frac{180}{\pi}+180$

\subsection{Vertical extrapolation of wind speed data}

As ERA-Interim wind speed data are given at $10 \mathrm{~m}$ a.g.l. and knowing that near-ground wind speed changes rapidly with height, the reanalyzed wind speed must be extrapolated to the wind turbine hub height in order to more realistically evaluate the wind energy production potential. In this study, the power law given by the following equation is applied [29,30]:

$\frac{V_{2}}{V_{1}}=\left(\frac{h_{2}}{h_{1}}\right)^{\alpha}$

where $V_{2}$ is the extrapolated wind speed at height $h_{2}, V_{1}$ is the available wind speed at height $h_{1}=10 \mathrm{~m}$ and $\alpha$ is the ground surface friction coefficient. Given that almost all of the study area is onshore, the $1 / 7$ power law [31] is adopted herein. In effect, this is the default value when no wind shear coefficient measurements are available at a given site [32].

\subsection{Wind energy outputs}

For wind energy output calculations, the characteristics of the Gamesa G52 wind turbine with a rated capacity of $850 \mathrm{~kW}$ are used, knowing that this is the only turbine model installed in Algeria, at the single wind park connected to the network in Adrar, in the south of the country. In this study, we used the nominal power curve given by the manufacturer to estimate the power output at each time step (with 6-h intervals). The characteristics of the selected wind turbine are summarized in Table 1 and the corresponding power curve is displayed in Fig. 2. The Gamesa G52 wind turbine characteristics used herein are provided by SKTM (Shariket Kahraba wa Taket Moutadjadida) company through an SKTM-CDER convention.

To estimate the energy output, the following method described in Ref. [33] was applied. First the power curve given by the manufacturer was directly used to estimate the power output $\left(P_{i}\right)$ at each time step $(i=1,2, \ldots, n)$. Then the gross mean power output $(P)$ over the whole studied sector is estimated by $\left(P=\frac{\sum P_{i}}{n}\right)$. Finally, the gross energy output $(E)$ for a period of time $(t)$ is calculated as $(E=P t)$.

Table 1

Gamesa G52 wind turbine parameters.

\begin{tabular}{ll}
\hline Model & Gamesa G52 \\
\hline Rated power $(\mathrm{kW})$ & 850 \\
Rotor diameter $(\mathrm{m})$ & 52 \\
Hub height $(\mathrm{m})$ & 55 \\
Swept area of rotor $\left(\mathrm{m}^{2}\right)$ & 2122 \\
Cut-in-wind speed $\left(\mathrm{m} \mathrm{s}^{-1}\right)$ & 4 \\
Rated wind speed $\left(\mathrm{m} \mathrm{s}^{-1}\right)$ & 15 \\
Cut-out-wind speed $\left(\mathrm{m} \mathrm{s}^{-1}\right)$ & 28 \\
\hline
\end{tabular}

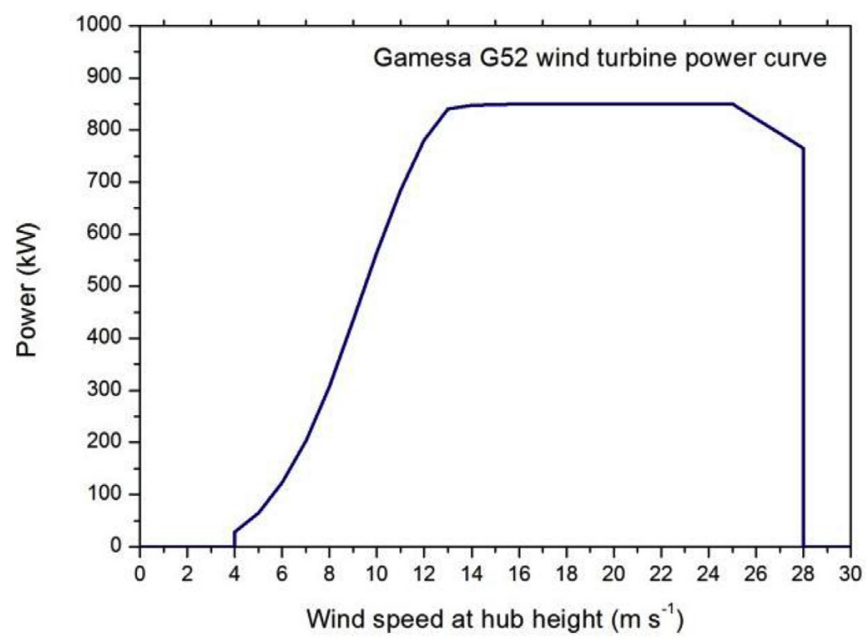

Fig. 2. Power curve in kW of the Gamesa G52 wind turbine.

\subsection{Observational data}

For the validation of the reanalysis wind fields, in situ daily mean wind speed, also at $10 \mathrm{~m}$ a.g.l., collected by a network of 42 weather stations across Algeria, were used. Nevertheless, due to the relatively low density of meteorological stations over Algeria and to the lack of regular wind speed measurements, with frequent data gaps, ERA-Interim data were validated for a single year period (2014), when data availability was maximum over all stations. Given the effect of the orography on wind speed [34], and since Algeria comprises several geographical areas, with differents reliefs and climates, from the northern Mediterranean coastline to the Sahara in its southernmost area, going through the Tell and the Highlands (in the Altas Mountain Range), the number of sites in each geographical zone is provided in Table 2. The geographical coordinates of the in situ meteorological stations and of the closest ERA-Interim griboxes are given in Table 3.

\subsection{Validation}

A comparison between ERA-Interim reanalysis and weather station measurements of daily mean wind speed, which are both at $10 \mathrm{~m}$ a.g.l., is herein carried out for 2014. The validation of the ERAInterim data was performed as follows. First, due to the fact that the 42 weather station records are of daily mean wind speed, the daily means of ERA-Interim wind speed at the nearest gridpoint were calculated. Furthermore, although the two-parameter Weibull function is conventionally used in wind energy assessments at different regions around the globe [35-37], the Generalized Extreme Value (GEV) distribution was herein chosen for this purpose, as it indeed corresponds to a generalization of the Weibull distribution, allowing more accurate representations of the empiral distributions $[38,39]$. The three-parameter GEV probability density function is defined as follows $[40,41]$ :

Table 2

Number of sites in each geographical area.

\begin{tabular}{ll}
\hline Site classification & Number of sites \\
\hline Littoral & 6 \\
Tell & 10 \\
Highlands & 12 \\
Sahara & 14 \\
\hline
\end{tabular}


Table 3

Geographical coordinates of 42 in situ wind measurement sites over Algeria, with data collected in 2014, and the closest ERA-Interim gridpoints.

\begin{tabular}{|c|c|c|c|c|c|c|c|}
\hline \multirow[t]{2}{*}{$\mathrm{Nb}$} & \multirow[t]{2}{*}{ Station } & \multicolumn{3}{|c|}{ Measurement site } & \multicolumn{3}{|c|}{ ERA-Interim gridpoint } \\
\hline & & Lon $\left(^{\circ}\right)$ & Lat $\left(^{\circ}\right)$ & Elev $(\mathrm{m})$ & Lon $\left(^{\circ}\right)$ & Lat $\left({ }^{\circ}\right)$ & Elev $(\mathrm{m})$ \\
\hline 1 & Adrar & -0.28 & 27.88 & 263 & 0.00 & 27.75 & 297 \\
\hline 2 & Ain-Safra & -0.60 & 32.76 & 1059 & -0.75 & 33.00 & 1296 \\
\hline 3 & Annaba & 7.81 & 36.83 & 4 & 7.50 & 36.75 & 15 \\
\hline 4 & Batna & 6.18 & 35.75 & 1052 & 6.00 & 36.00 & 1005 \\
\hline 5 & Bechar & -2.23 & 31.50 & 773 & -2.25 & 31.50 & 775 \\
\hline 6 & Bejaia & 5.06 & 36.71 & 2 & 5.25 & 36.75 & 0 \\
\hline 7 & Biskra & 5.73 & 34.80 & 87 & 6.00 & 34.50 & -7 \\
\hline 8 & Borj Bou Arreridj & 4.76 & 36.06 & 930 & 4.50 & 36.00 & 1366 \\
\hline 9 & Bou-Saada & 4.20 & 35.33 & 461 & 4.50 & 35.25 & 570 \\
\hline 10 & Chlef & 1.33 & 36.21 & 143 & 1.50 & 36.00 & 776 \\
\hline 11 & Constantine & 6.61 & 36.28 & 694 & 6.75 & 36.00 & 1014 \\
\hline 12 & Dar-El-Beida & 3.25 & 36.68 & 25 & 3.00 & 36.75 & 225 \\
\hline 13 & Djanet & 9.46 & 24.26 & 1054 & 9.75 & 24.00 & 982 \\
\hline 14 & El-Bayadh & 1.00 & 33.66 & 1347 & 0.75 & 33.75 & 1276 \\
\hline 15 & El-Kheiter & 0.06 & 34.15 & 1001 & 0.00 & 34.50 & 1096 \\
\hline 16 & Ghardaia & 3.81 & 32.40 & 450 & 3.75 & 32.25 & 460 \\
\hline 17 & Ghazaouet & -1.86 & 35.10 & 5 & -1.50 & 35.25 & 237 \\
\hline 18 & Illizi & 8.41 & 26.50 & 558 & 8.25 & 26.25 & 781 \\
\hline 19 & In-Amenas & 9.63 & 28.05 & 562 & 9.75 & 27.75 & 534 \\
\hline 20 & In-Salah-North & 2.51 & 27.25 & 269 & 3.00 & 27.00 & 357 \\
\hline 21 & Jijel-Achouat & 5.78 & 36.80 & 2 & 6.00 & 36.75 & 538 \\
\hline 22 & Kasr-Chellala & 2.31 & 35.16 & 801 & 2.25 & 35.25 & 804 \\
\hline 23 & Laghouat & 2.93 & 33.76 & 765 & 3.00 & 33.75 & 746 \\
\hline 24 & Mascara-Ghriss & 0.15 & 35.21 & 513 & 0.00 & 35.25 & 620 \\
\hline 25 & Mechria & -0.43 & 33.58 & 1149 & -0.75 & 33.75 & 1079 \\
\hline 26 & Milliana & 2.23 & 36.30 & 721 & 2.25 & 36.00 & 556 \\
\hline 27 & Mostaganem & 0.11 & 35.88 & 138 & 0.00 & 36.00 & 0 \\
\hline 28 & Msila & 4.50 & 35.66 & 442 & 4.50 & 36.00 & 1365 \\
\hline 29 & Naama & -0.30 & 33.26 & 1166 & 0.00 & 33.00 & 1094 \\
\hline 30 & Oran Es Senia & -0.60 & 35.63 & 90 & -0.75 & 36.00 & 0 \\
\hline 31 & Ourgla & 5.40 & 31.93 & 141 & 5.25 & 32.25 & 163 \\
\hline 32 & Relizane & 0.55 & 35.73 & 75 & 0.75 & 36.00 & 44 \\
\hline 33 & Saïda & 0.15 & 34.86 & 752 & 0.00 & 34.50 & 1096 \\
\hline 34 & Setif & 5.41 & 36.18 & 1038 & 5.25 & 36.00 & 901 \\
\hline 35 & Sidi-Belabes & -0.61 & 35.20 & 476 & -0.75 & 35.25 & 563 \\
\hline 36 & Tamanrasset/Aguenna & 5.46 & 22.80 & 1377 & 5.25 & 22.50 & 1065 \\
\hline 37 & Tebessa & 8.13 & 35.41 & 813 & 8.25 & 35.25 & 1102 \\
\hline 38 & Tiaret & 1.43 & 35.35 & 1127 & 1.50 & 35.25 & 1018 \\
\hline 39 & Timimoun & 0.28 & 29.25 & 312 & 0.00 & 29.25 & 346 \\
\hline 40 & Tindouf & -8.13 & 27.70 & 431 & -8.25 & 27.75 & 459 \\
\hline 41 & Tlemcen-Zenata & -1.46 & 35.01 & 247 & -1.50 & 35.25 & 237 \\
\hline 42 & Touggourt & 6.13 & 33.11 & 85 & 6.00 & 33.00 & 78 \\
\hline
\end{tabular}

$f(v)=\frac{1}{\alpha} \exp \left\{-\left[1+k \frac{(v-\mu)}{\alpha}\right]^{-\frac{1}{k}}\right\}\left[1+k \frac{(v-\mu)}{\alpha}\right]^{-1-\frac{1}{k}}$

for $k(v-\mu) / \alpha>-1$, where $f(v)$ is the probability of observing a given wind speed, $v, \mu$ is the location parameter, $\alpha$ is the scale parameter and $k$ is the shape parameter. The average wind speed $v_{m}$ can be calculated on the basis of the GEV parameters, as given below [38]:

$v_{m}=\mu+\frac{\alpha}{k}[1-\Gamma(1+k)]$

For a good results reading, two metrics defined in Ref. [42] were selected to assess the accuracy of the reanalysis dataset, i.e. the mean absolute error (MAE) and mean absolute percentage error (MAPE). The absolute value was added to the mean percentage error to evaluate only the difference, without considering the wind potential overestimation or underestimation.

In order to assess whether the observed and the ERA-Interim data have the same empirical distributions (sample withdrawn from the same population), the two-sample Kolmogorov-Smirnov (KS) test [43] is applied, at 5\% significance level. In the KS test, the null hypothesis states that the two samples belong to the same population, against the alternative hypothesis that they are from different populations [44,45]. The KS test is modified to determine if the two distributions have the same shape only, without taking into consideration their medians. The Wilcoxon-Mann-Whitney (WMW) test [43] is applied to compare the medians at 5\% significance level. The WMW null hypothesis considers that the two samples belong to populations with equal medians [44,46].

\section{Results and discussion}

\subsection{Validation of ERA-Interim wind data}

Fig. 3 illustrates the spatial distribution of the annual mean $10 \mathrm{~m}$ wind speed for 2014, estimated using the GEV distribution, for the observed data (circles) and for the ERA-Interim reanalysis (shading). A higher homogeneity in the wind speed values at the sites located in the south of the country is observed. Figs. 4 and 5 display the errors in the wind speed of ERA-Interim data compared to observed wind speeds, showing $\operatorname{MAE}\left(\mathrm{m} \mathrm{s}^{-1}\right)$ and MAPE (\%) by site classifications. Fig. 4 shows that the results mirrored those observed in the spatial distribution given in Fig. 3 for the Sahara sites, where MAE and MAPE have lower values in 


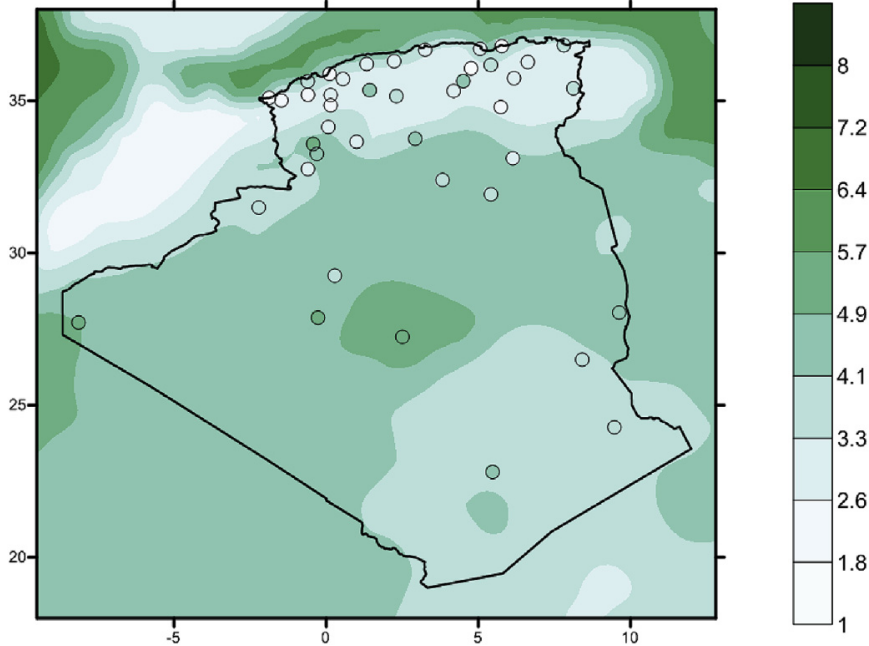

Fig. 3. Spatial distribution of 42 measurement points, along with annual mean wind speed for 2014 (circles) and over the $10 \mathrm{~m}$ wind map from ERA-Interim (shading in $\left.\mathrm{m} \mathrm{s}^{-1}\right)$.

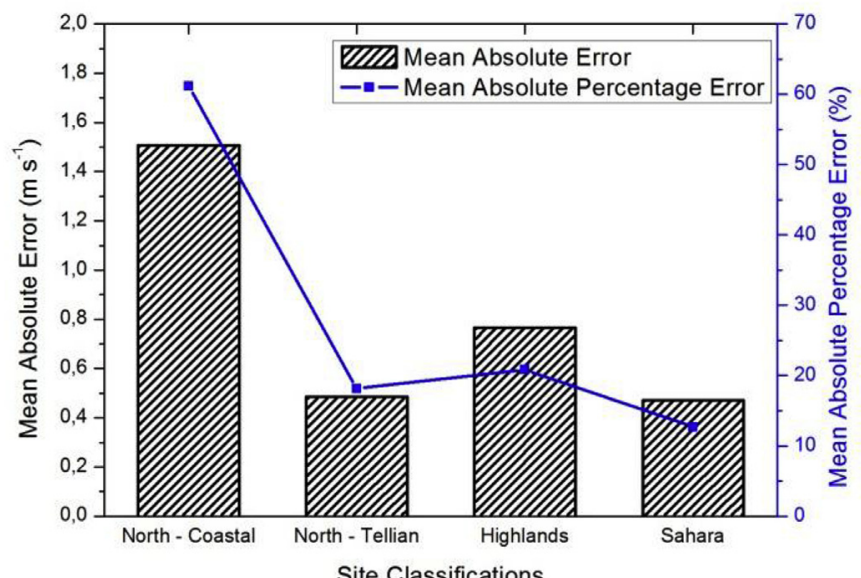

Fig. 4. Error in wind speed of ERA-Interim data in each of the four site classifications regarding Algerian topography, compared to in situ measured wind speeds.

the more northern sites, i.e. $0.47 \mathrm{~m} \mathrm{~s}^{-1}$ and $12.71 \%$, respectively However, at Tellian sites in the north, the results are not so different from those of the Sahara sites in terms of MAE, while the MAPE is about $8 \%$ higher. The results for the highland sites show MAE equal to $0.76 \mathrm{~m} \mathrm{~s}^{-1}$ and MAPE near 21\%. The Algerian coastal sites reveal the worst results, with the highest MAE and MAPE, equal to $1.5 \mathrm{~m} \mathrm{~s}^{-1}$ and $61.18 \%$, respectively.

The results for each site reveal that Batna, in Algerian Highlands, presents the highest agreement between observed and reanalyzed wind speed (Fig. 5). Fig. 4 also highlights that the worst results are found in the coastal sites, where the highest value of MAE is equal to $2.19 \mathrm{~m} \mathrm{~s}^{-1}$ at Oran Es Senia site, while the highest value of MAPE is found in Ghazaouet (107\%). In addition, among the 42 analyzed sites and taking into consideration the MAPE evolution, it is worth noting that there are 20 sites where the error is $<15 \%$, of which 12 sites are from the Sahara, 5 from North-Tellian, 3 from the highlands and none from the coastline. This can be partly explained by the deviations between weather stations and the ERA-Interim nearest gridpoint, where the gridpoints corresponding to 4 out of 7 sites in the north coast fall offshore, on the Mediterranean sea.
These sites are Ghazaouet, Mostaganem, Oran Es Senia and Bejaia, of which the MAPE results are the worst (>50\%) among the 42 analyzed sites.

In order to better understand the behavior of wind speed in Algeria, Fig. 6 shows the time series weather data during the year 2014, for a representative region of each site classification regarding Algerian topography. It is worth noticing that in the three northern geographical areas in Algeria (Lottoral, Tell and Highlands) the wind remains relatively calm during the warm months (from June to October), whereas the wind speed tends to increase for the rest of the year. However, for the Algerian Sahara (Fig. 6-d), it is seen that the wind is relatively important throughout the year, with a maximum reached in the period from February to March.

Fig. 7 depicts the wind deviation errors as a function of the elevation difference between weather stations and the nearest gridpoint from ERA-Interim. Higher errors in both MAE and MAPE tend to be related to higher elevation differences. Thus, it is important to emphasize that mountainous areas and strong local winds are not entirely resolved by ERA-Interim, which is due to its coarse spatial resolution of $0.75^{\circ}$ latitude $\times 0.75^{\circ}$ longitude $(\sim 70-80 \mathrm{~km}$ grid spacing). Hence, the present assessments are essentially focused on large-scale features. In order to accurately downscale this information, mesoscale models should be coupled with reanalysis and should also be complemented by the installation of local wind sensors, an approach that is out of the scope of the present study.

The GEV distributions at $10 \mathrm{~m}$ for the different weather stations and the corresponding nearest gridpoint from ERA-Interim and for 2014 are divided by tests result and plotted in Figs. 8-11. The respective boxplots and the KS and WMW test results are also shown. Fig. 8 depicts the sites where the two tests were validated. Fig. 9 gives results for sites where only the KS test was validated. Fig. 10 shows the results for the site where only the WMW test provided validation, while Fig. 11 gives the rest of the sites, where both tests were rejected. Fig. 8 shows only two sites where the two datasets are drawn from the same distribution and with an equal median. From Fig. 9, it is observed that at 9 sites among the 42 analyzed, the in situ measurement and ERA-Interim datasets are drawn from the same distribution, but have different medians. Conversely, from Fig. 10, it is observed that 11 sites with equal medians, but not having similar distributions. Regarding Fig. 11 and 20 sites present different distributions and medians. The results from KS and WMW tests are summarized in Fig. 12.

In agreement with the previous results regarding MAE and MAPE, Fig. 12 shows that among the 7 sites located on the coast, the two tests were rejected at 5 sires, though 4 of them correspond to ERA-Interim griboxes falling on the Mediterranean Sea. Furthermore, from the 15 sites located in the Sahara (southern Algeria), there are only 4 sites where both tests are rejected. The rest of the Sahara sites have databases that have either the same distribution or an equal median, except for the site of In-Amenas, in the extreme southeast, where the two tests showed agreement between data. The second site where both tests were validated is Mascra-Ghriss, located in northern Tell. This part of Algeria includes 4 sites among 9 where the two tests were rejected, while an almost identical ratio is found in the Highlands, with 5 sites from 11, where both KS and WMW tests were rejected. Therefore, for 2014, more than one half of the analyzed sites either present the same distribution or equal medians. Hence, a reasonable agreement between ERA-Interim wind data and observations is found, but it should be bear in mind that the ERA-Interim reanalysis only capture largescale features of the wind patterns, not properly resolving local winds, which may be particularly relevant in mountainous and coastal areas. This gap between large-scale wind and local winds, measured by weather stations, should be taken into account when 

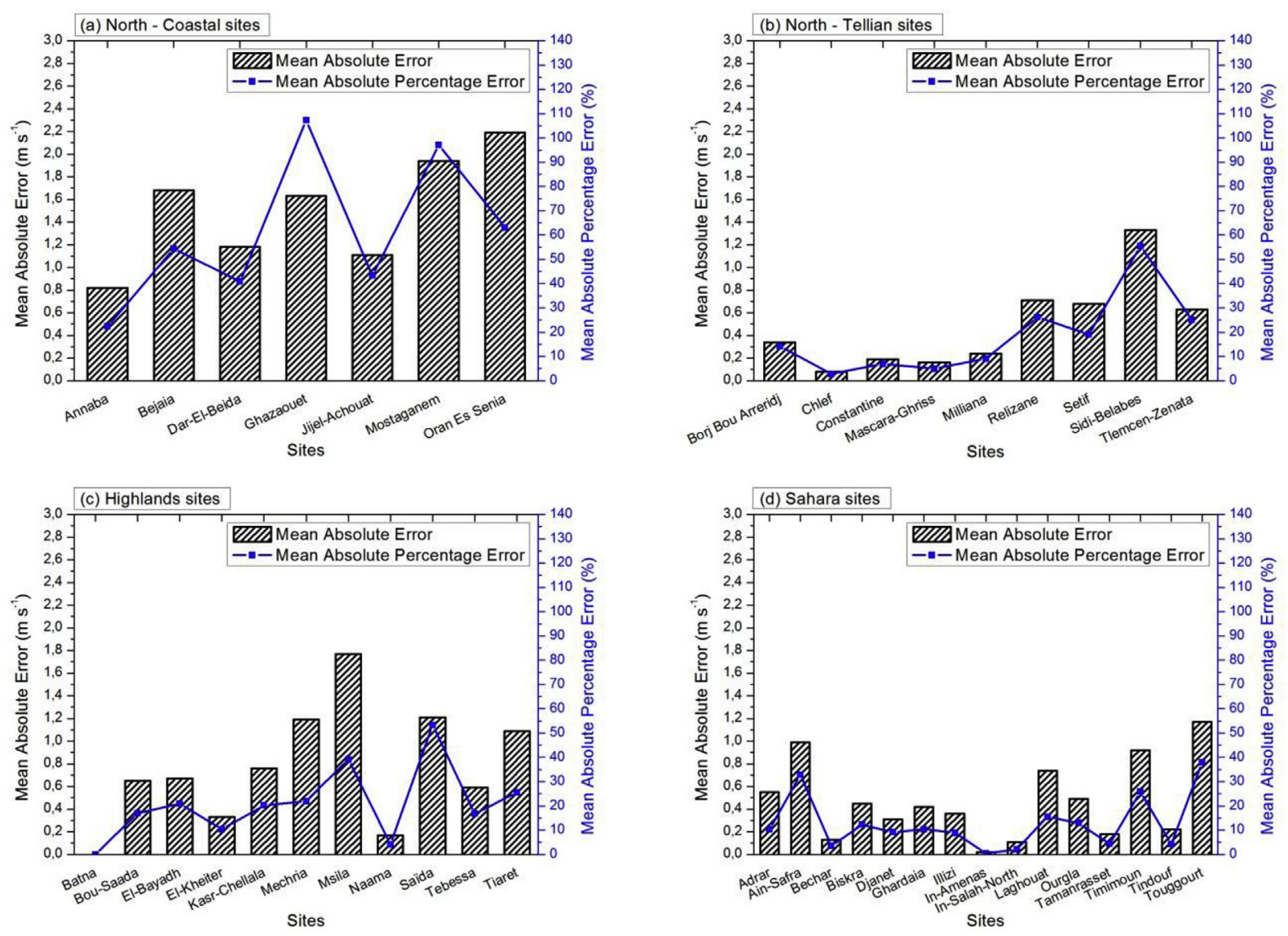

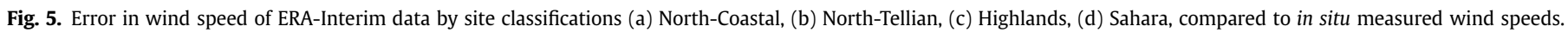

interpreting the discrepancies found between reanalyzed and observed winds.

\subsection{Wind resource maps}

Wind speed and prevailing wind direction from ERA-Interim, at $10 \mathrm{~m}$ and for the period 1981-2014 over Algeria are shown in Fig. 13. Although wind speeds are, as expected, greater over the sea than over land, the wind map shows that the mean wind speed in Algeria exceeds $5 \mathrm{~m} \mathrm{~s}^{-1}$ in the south, on the most windy area limited as follows: $26^{\circ}-29^{\circ} \mathrm{N}, 1^{\circ} \mathrm{W}-5^{\circ} \mathrm{E}$. Moreover, the Algerian Sahara is windier than the northern part of the country. It is still worth noting that the prevailing winds in Algeria are mostly easterlies over the Sahara and westerlies over northern Algeria.

The maximum mean wind speed equals to $5.3 \mathrm{~m} \mathrm{~s}^{-1}$, with a predominantly East-North-Easterly wind located at the site of In Salah, with the following coordinates: $27.26^{\circ} \mathrm{N}$ and $2.73^{\circ} \mathrm{E}$. Despite the lower average wind speed, these results are in accordance with the last updated wind map, established in 2018 [7], which no longer shows the Aadrar region as the windiest region in Algeria, as seen in the previous Algerian wind atlases [4-6,47]. On the other hand, it is shown that the minimum mean wind speed, with a value of $2.3 \mathrm{~m} \mathrm{~s}^{-1}$ and predominantly blowing from the northwest, is located in the Batna region, in the Eastern part of Algerian Highlands, with the following geographic coordinates: $35.41^{\circ} \mathrm{N}$ and $6.02^{\circ}$ E. However, according to the last update of the Algerian Wind Atlas [7], it is the site of Maghnia in the extreme northwest, with the Morrocan boundary and open to the Mediterranean sea, which represents the least windy region, with an annual mean wind speed of less than $3 \mathrm{~m} \mathrm{~s}^{-1}$. Although the south of the country is windier than the north, southeastern Algeria, near the Ahaggar region $\left(24.44^{\circ} \mathrm{N}\right.$ and $\left.5.91^{\circ} \mathrm{E}\right)$, remains relatively less windy, with an average wind speed of $3.3 \mathrm{~m} \mathrm{~s}^{-1}$, when compared to the rest of the Sahara region, where the mean wind speed exceeds $4 \mathrm{~m} \mathrm{~s}^{-1}$.

To estimate the wind resource in any region for energy production, it is important to quantify not only the average energy resource, but also the expected variability at different levels by establishing different assessments, such as an analysis of the diurnal and monthly timescales. Fig. 14 gives the monthly maps of the wind resource over Algeria. The period between March and August is clearly the windiest over most of southern Algeria, while the period between February and April is the windiest in the north. On the other hand, the less windy period in the south is from October to December, while in the north it extends over a longer period, from June to October. This is generally consistent with the latest study on monthly variability [6], where it was found that the period from March to June is the windiest throughout the country, while the autumnal months are the least windy. Regarding the prevailing wind direction, in northern Algeria winds are predominantly westerly from October to April, while during the period from May to September easterly winds occur over the Highlands. Additionally, over the windiest area in Algeria, near In Salah, winds are predominantly east-north-easterly throughout the year, where the maximum mean wind speed reaches $6 \mathrm{~m} \mathrm{~s}^{-1}$ in July. Nonetheless, in the latest study on monthly variability [6], the highest monthly mean wind speed is assessed in May, with $8.2 \mathrm{~m} \mathrm{~s}^{-1}$ at Hassi R'mel region, $600 \mathrm{~km}$ further north.

In order to provide additional information on the wind conditions over Algeria, the hourly evolution of the mean wind speed is presented in Fig. 15. Important diurnal changes are apparent, 

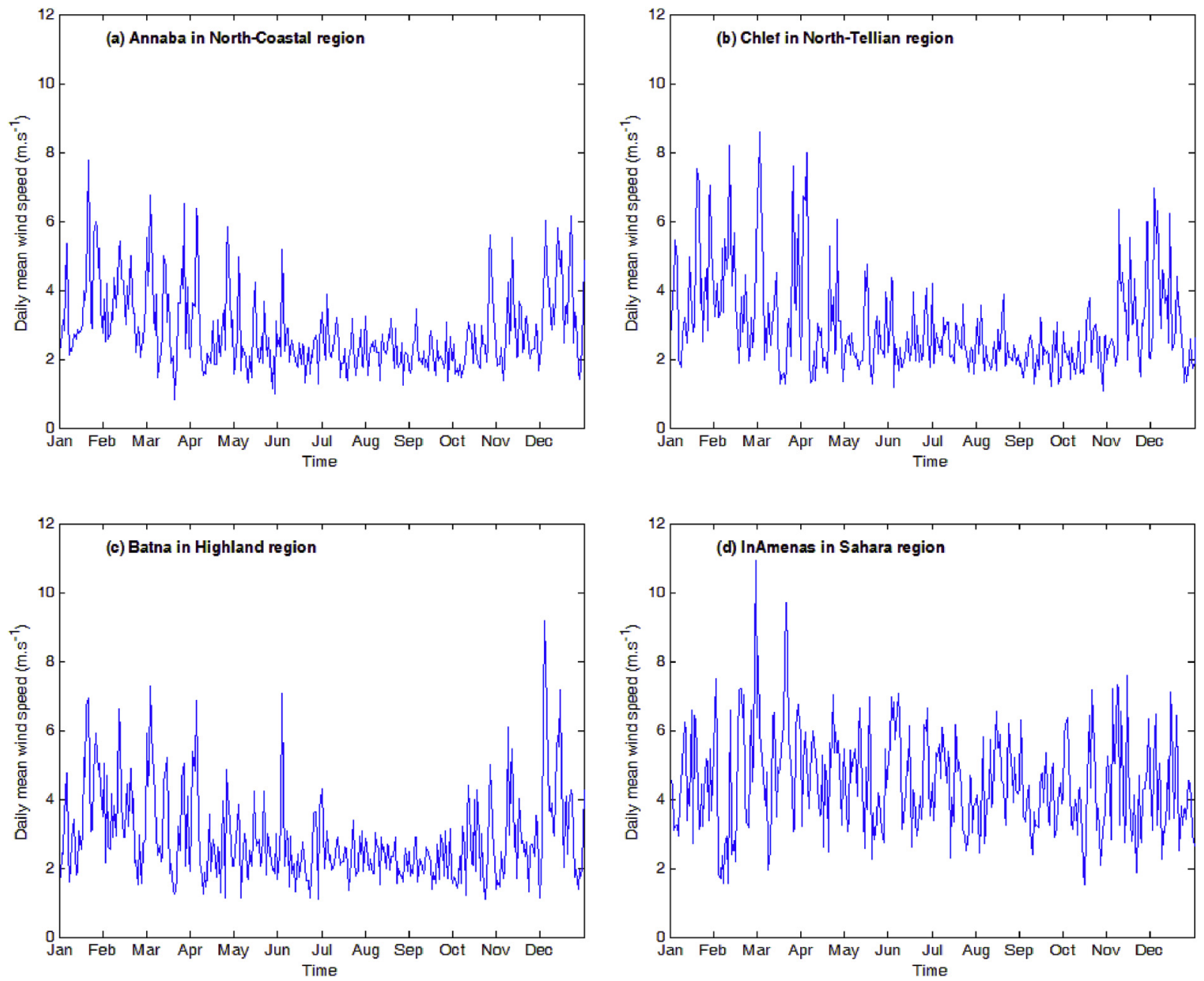

Fig. 6. Time series weather data for a representative weather station of each region during 2014 .
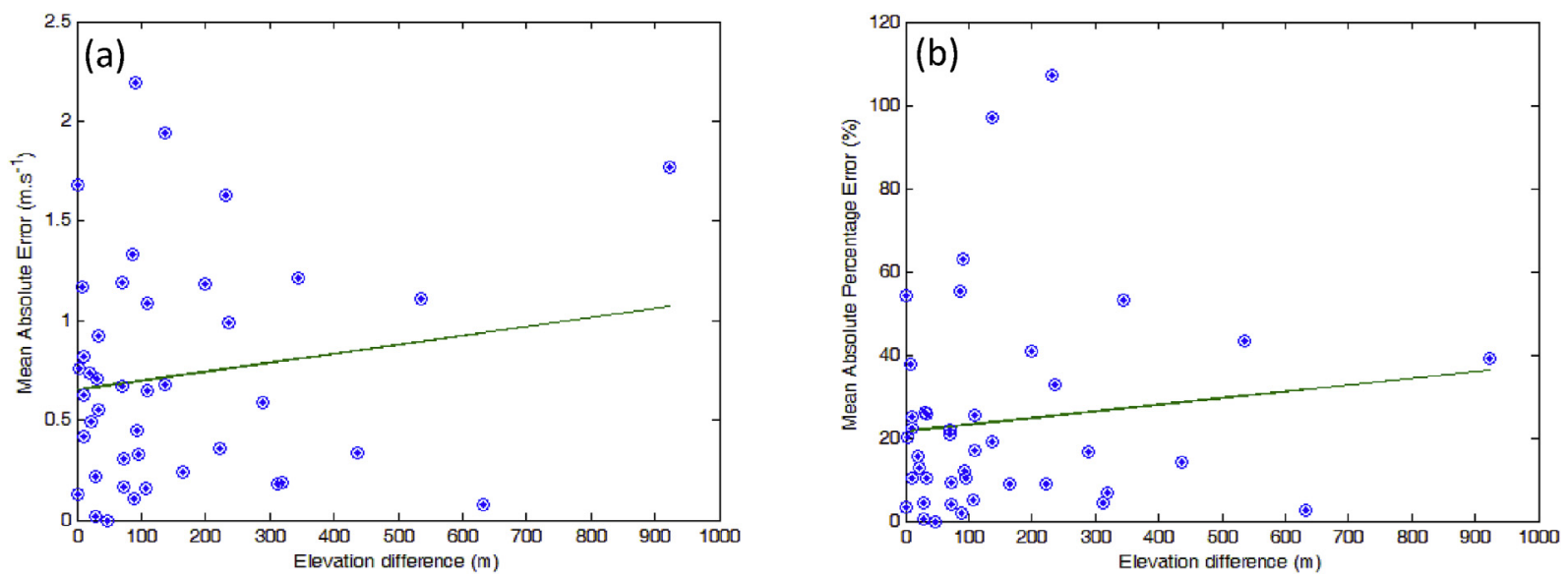

Fig. 7. Wind errors (a) MAE and (b) MAPE, as a function of the elevation difference between weather stations and the nearest gridpoint from ERA-Interim.

particularly in southeastern Algeria at 06 and 12 UTC (Coordinated Universal Time). The minimum value was recorded at 06 UTC $\left(1.9 \mathrm{~m} \mathrm{~s}^{-1}\right)$ in the northeast $\left(35.57^{\circ} \mathrm{N}\right.$ and $\left.5.76^{\circ} \mathrm{E}\right)$, while the maximum value is obtained at 12 UTC $\left(5.8 \mathrm{~m} \mathrm{~s}^{-1}\right)$ still at the windiest area of Algeria, located in the south, near In Salah, where wind rarely blows from the north or even from the west, but is predominantly from northeast at 00, 06 and 18 UTC and from east at 12 UTC. Overall, Algeria is windy as a whole at 12 UTC, while relatively weak winds prevail at nighttime.

In terms of wind direction, nearly the same pattern is found, i.e. mainly easterlies in the south and westerlies in the north at 00, 06 and 12 UTC. However, different results can be found at 18 UTC, 

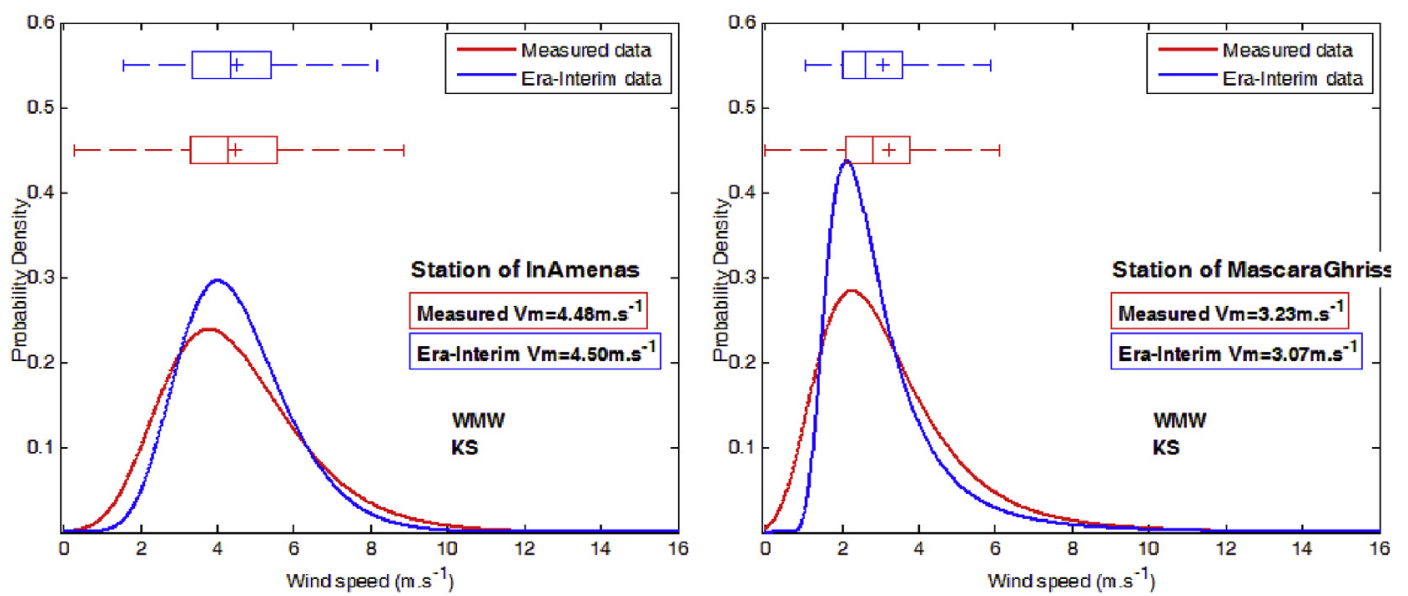

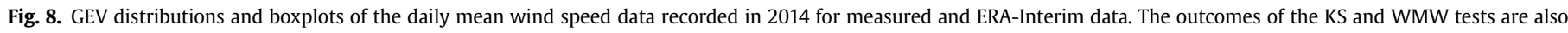
shown, with no ${ }^{*}$ indicating the validation of both tests.
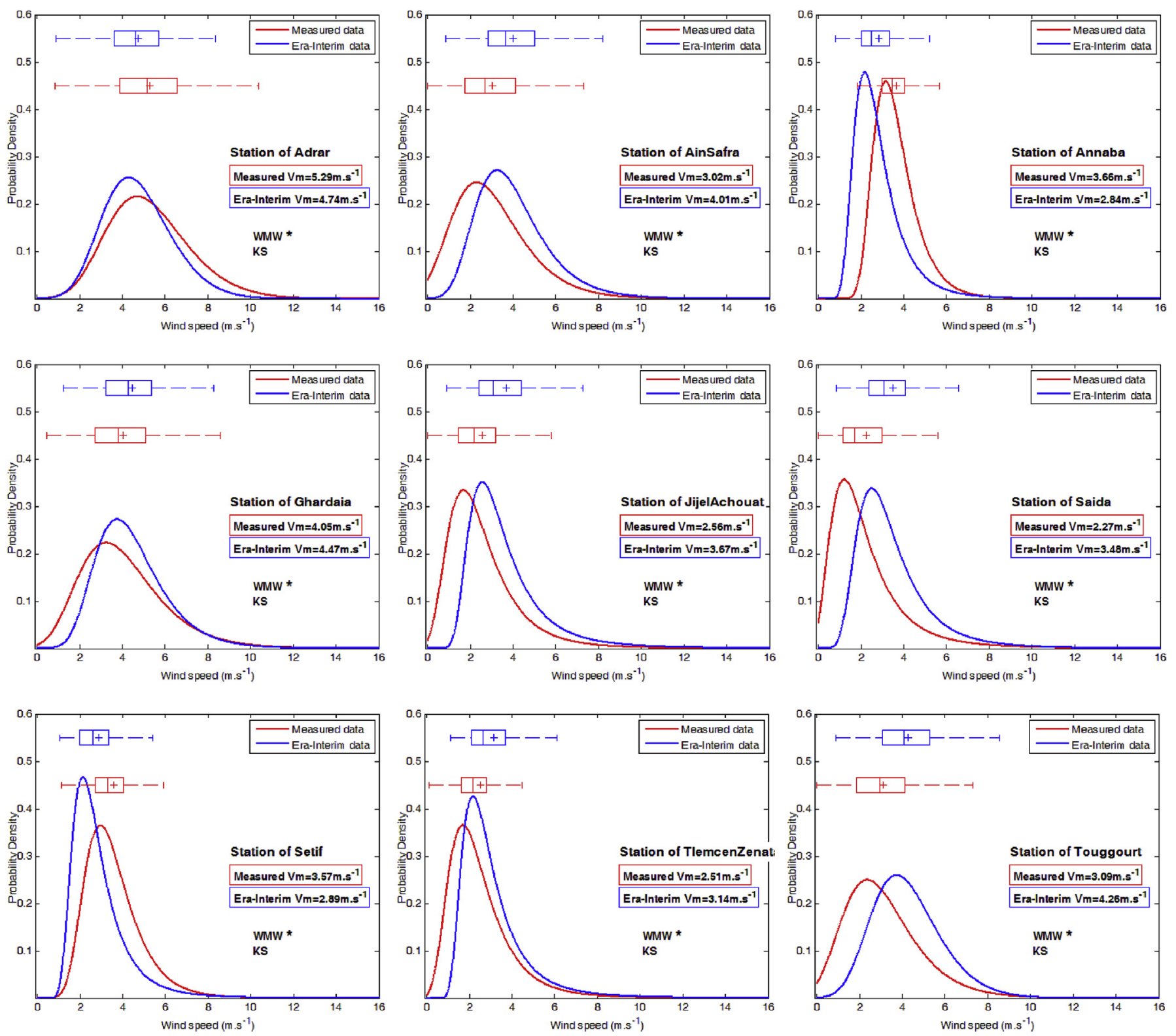

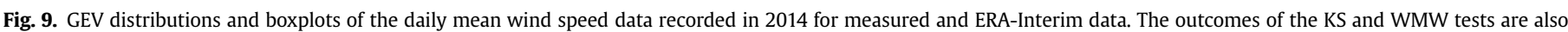
shown, with an * indicating a rejection of the null hypothesis for the WMW test. 
where northerly and southerly winds appear simultaneously in northeastern Algeria, whilst northerly and westerly winds arise over the rest of northern Algeria. With respect to southern Algeria, at 18 UTC, even though winds are predominantly from northeast
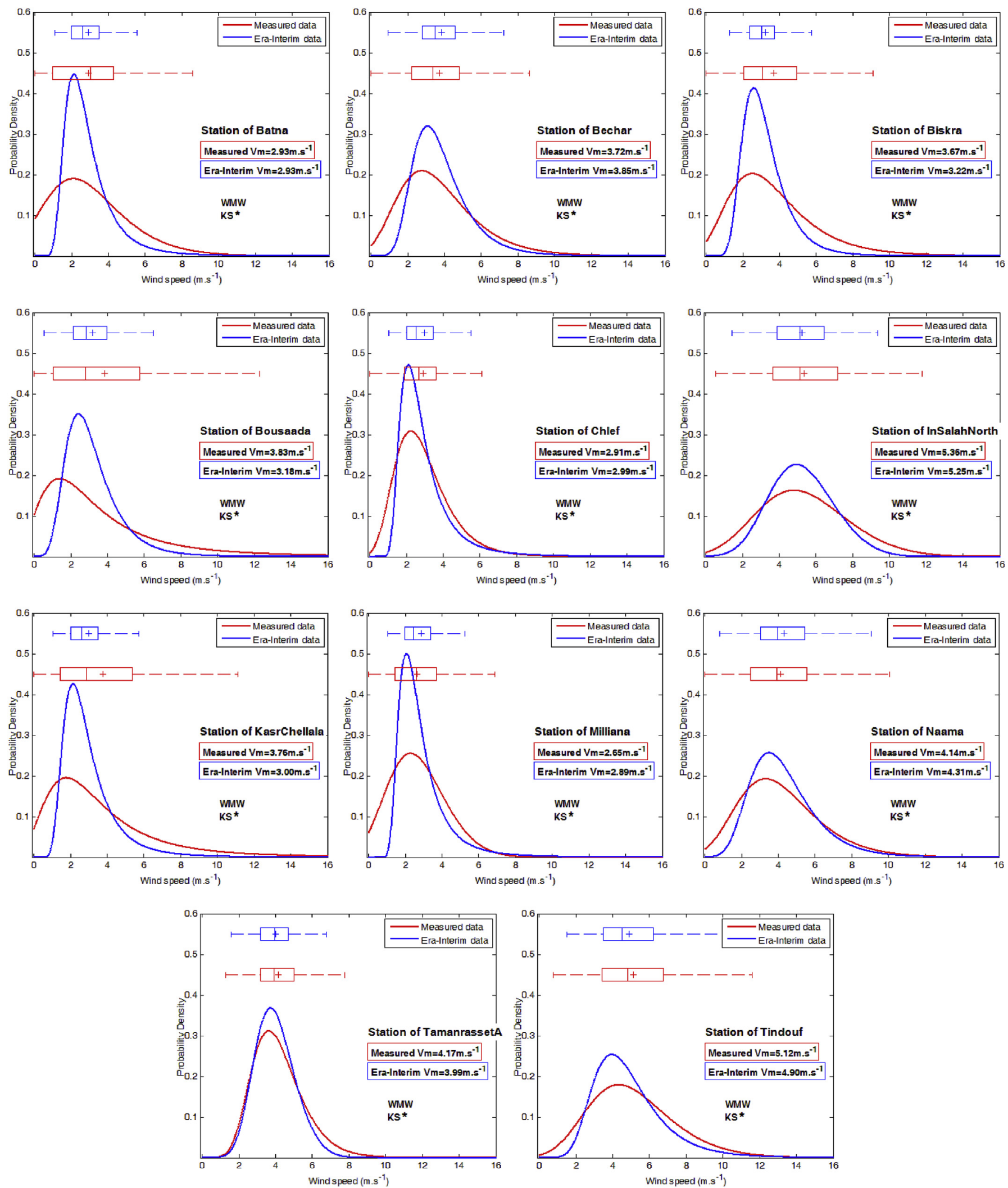

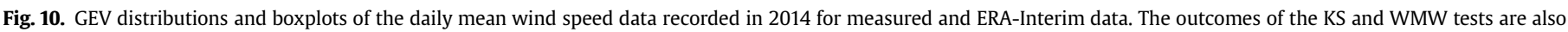
shown, with an *indicating a rejection of the null hypothesis for the KS test. 

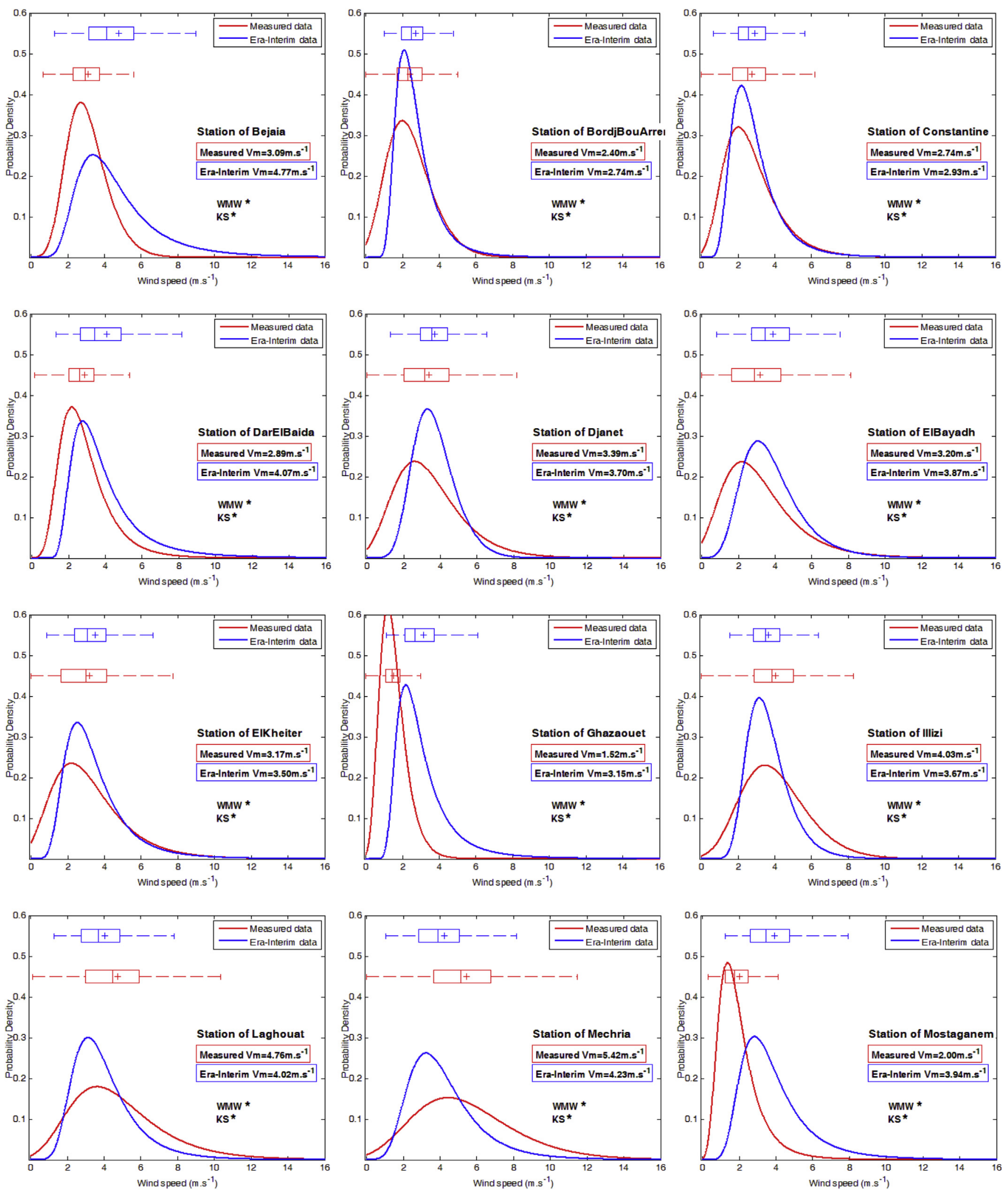

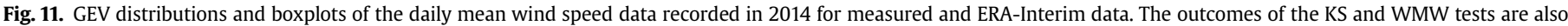
shown, with an * indicating a rejection of the null hypothesis for both tests. 

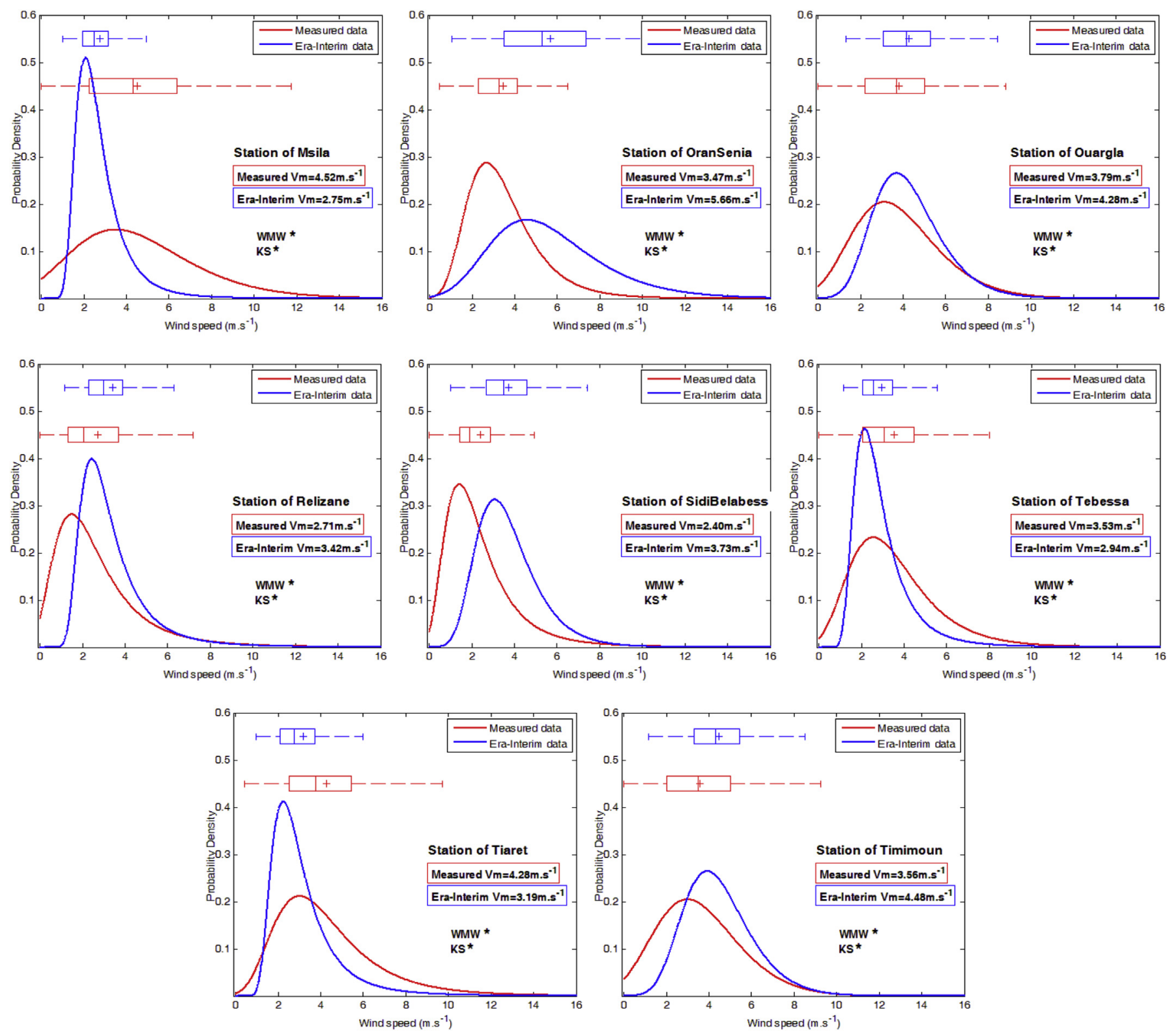

Fig. 11. (continued).

over most of the Algerian Sahara, a clear shift in wind direction over southeastern Algeria can be found, where wind blows simultaneously from the east, west and north.

\subsection{Wind energy map}

By taking into account the wind speed calculated during the 33year wind reanalysis at $10 \mathrm{~m}$ over the whole study sector (28 latitudes $\times 32$ longitudes $=896$ gridpoints) and the characteristics of the Gamesa wind turbine, the wind energy output on a daily basis has been computed and plotted in Fig. 16 for a hub height at $55 \mathrm{~m}$. In line with the previous results, the site of In Salah, southern Algeria, is the region with the highest daily wind energy potentially generated by the selected wind turbine, reaching $6 \mathrm{MWh}_{\mathrm{day}}{ }^{-1}$. Further, most of the Algerian Sahara shows quite acceptable results for wind energy production, around $4 \mathrm{MWh} \mathrm{day}^{-1}$, except over the southeasternmost region, where the potential is often less than
$2 \mathrm{MWh}$ day $^{-1}$, with a minimum value of only $1.65 \mathrm{MWh} \mathrm{day}^{-1}$ assessed at the geographical coordinates: $24.55^{\circ} \mathrm{N}$ and $5.57^{\circ} \mathrm{E}$.

Regarding northern Algeria, northwards of the $33^{\circ} \mathrm{N}$ parallel, the results suggest a minimum production of about $0.36 \mathrm{MWh}^{\mathrm{M}} \mathrm{day}^{-1}$ in the northwest, near the borders with Morocco, at the site of Tlemcen $\left(34.94^{\circ} \mathrm{N}, 1.30^{\circ} \mathrm{W}\right)$. Furthermore, for most of the Mediterranean coastline, particularly in the west, the daily energy production can reach a maximum of $4 \mathrm{MWh}$, while in the western part of the Highlands the maximum is of about 3.2 $\mathrm{MWh} \mathrm{day}^{-1}$, near the site of Mechria $\left(33.53^{\circ} \mathrm{N}, 0.09^{\circ} \mathrm{W}\right)$.

However, in this study, we analyzed only the theoretical potential, which is the highest level of resource potential and only takes into account restrictions concerning natural and climatic parameters. Thus, it is important to stress that the following different types of wind potentials should be considered for a deep wind resource assessment in forthcoming research: 


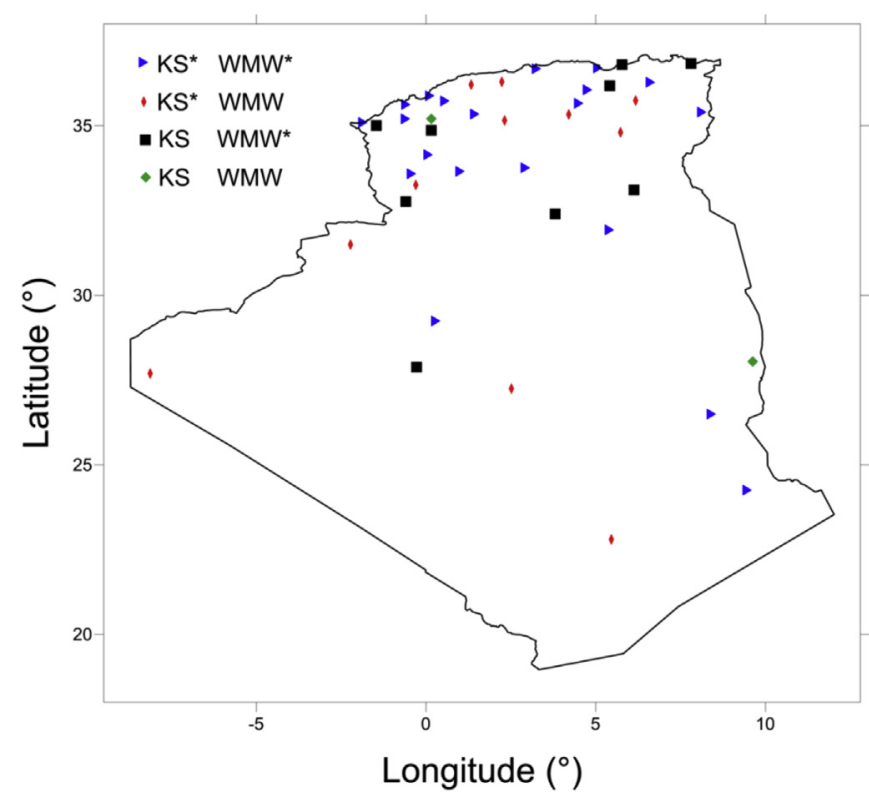

Fig. 12. Spatial distribution of the 42 measurement points over Algeria, along with the outcomes from the WMW and KS tests between observations and ERA-Interim data for 2014 and at $10 \mathrm{~m}$ a.g.l. * indicates a rejection of the null hypothesis (no validation).

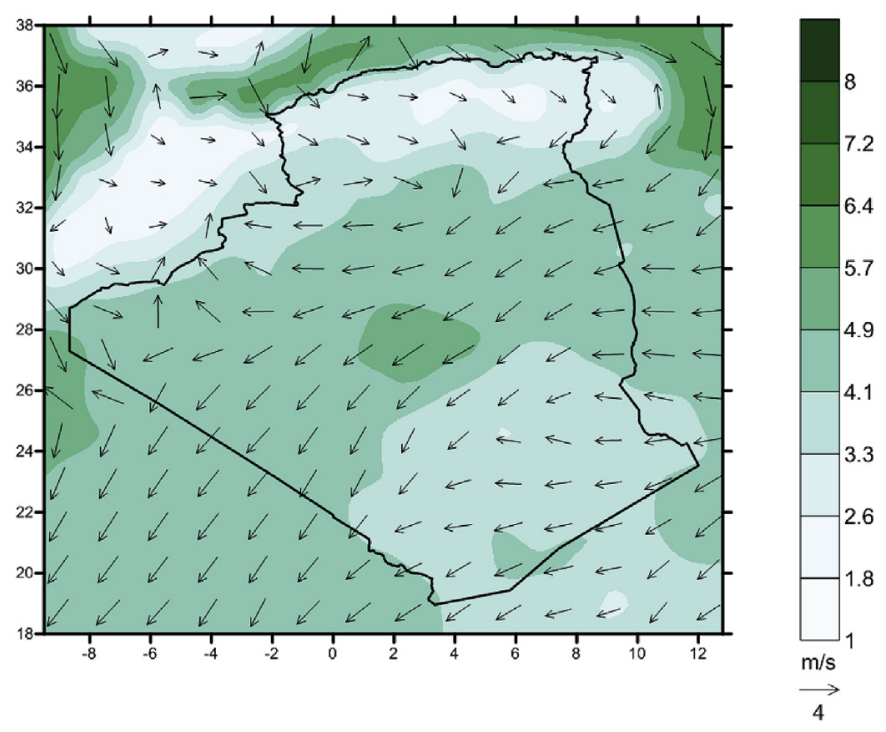

Fig. 13. Mean wind speed distribution over Algeria (contours), along with the prevailing wind direction (arrows), using ERA-Interim data for the period 1981-2014 at $10 \mathrm{~m}$ a.g.l.

- Geographical potential is the theoretical potential limited by the resources at geographic locations that are suitable for installation of specific technologies, such as wind energy farms,

- Technical potential is the geographical potential that can be attained using technically available technologies while accounting for conversion efficiencies,

- Techno-economic potential is that achievable by applying technically feasible and economically-viable technologies universally used in competitive markets,

- Economic potential is the technical potential at cost levels considered competitive.

In several previous studies, these assessments were already carried out for selected sites in Algeria [48-51].

\section{Summary and conclusions}

The present study contributes to a better assessment of the actual wind map in Algeria, using for the first time a reanalysis dataset. For this purpose, gridded $10 \mathrm{~m}$ zonal and meridional wind components from the ERA-Interim and for the period 1981-2014 were used. This dataset was also applied to assess the wind energy production potential over the whole of the Algerian territory.

The ERA-Interim data were validated with in situ measurements for 2014, collected by a network of 42 sites spread throughout Algeria. A good agreement between reanalysis and observations was found in the south, whereas a much weaker agreement was found near the coastline. At this point, it should be stressed that the ERA-Interim reanalysis is not able to capture local-scale wind features, particularly over the complex orography of mountainous areas. As such, in general, the agreement between reanalyzed wind and weather station wind measurements is not expected to be high, mostly over the aforementioned areas. To summarize:

- The MAE ranges from zero to $2.2 \mathrm{~m} \mathrm{~s}^{-1}$ by site, while it ranges from $0.47 \mathrm{~m} \mathrm{~s}^{-1}$ in the Sahara to $1.5 \mathrm{~m} \mathrm{~s}^{-1}$ in the coast by site classification;

- Concerning the MAPE by site, the minimum equals to zero at Batna in the Highlands, and a maximum of $107 \%$ at Ghazaouat near the Mediterranean coastline. By site classification, the MAPE varies between $12.71 \%$ in the Sahara sites and $61.18 \%$ in the Mediterranenan coast;

- The KS and WMW test results reveal that among the 42 sites analyzed, 22 sites show an agreement between reanalysis and observations at least in one of the two tests.

Regarding the variability assessment of both the mean speed and prevailing winds, carried out at the monthly and hourly timescales, using the 33-year wind reanalysis dataset, it has been found that:

- The Algerian Sahara is windier than northern Algeria, where the maximum mean wind speed was assessed at In Salah $\left(5.3 \mathrm{~m} \mathrm{~s}^{-1}\right.$ with a predominantly east-northeasterly wind direction). The minimum mean wind speed equals to $2.3 \mathrm{~m} \mathrm{~s}^{-1}$, predominantly northwesterly wind, was evaluated at Batna, northeastern Algeria.

- For southern Algeria, the windiest period is between March and August, while the period from October to December is much less windy.

- For the north, the windiest period is between February and April, while the less windy period is from June to October.

- During daytime (12 UTC), the Algerian territory is windy as a whole, while at nighttime winds are relatively calm.

The computed wind energy output for the Gamesa G52 $(850 \mathrm{~kW})$ provides reasonably high wind energy production potential $\approx 4 \mathrm{MWh} \mathrm{day}^{-1}$ over most of the Algerian Sahara and of the Mediterranean coastline, where a maximum of $6 \mathrm{MWh}^{\mathrm{May}}{ }^{-1}$ can be achieved in the south.

Owing to the low density of weather stations over Algeria and to the lack of uninterrupted and homogeneous wind speed measurements, the use of reanalyses datasets can be a good alternative for wind resource assessments, providing some preliminary validation of the reanalyzed wind fields with observations. Nonetheless, ERA-Interim gridded wind fields were herein applied only for assessing large-scale wind features over Algeria. In sites where strong local winds play an important role, such as sea or mountain 

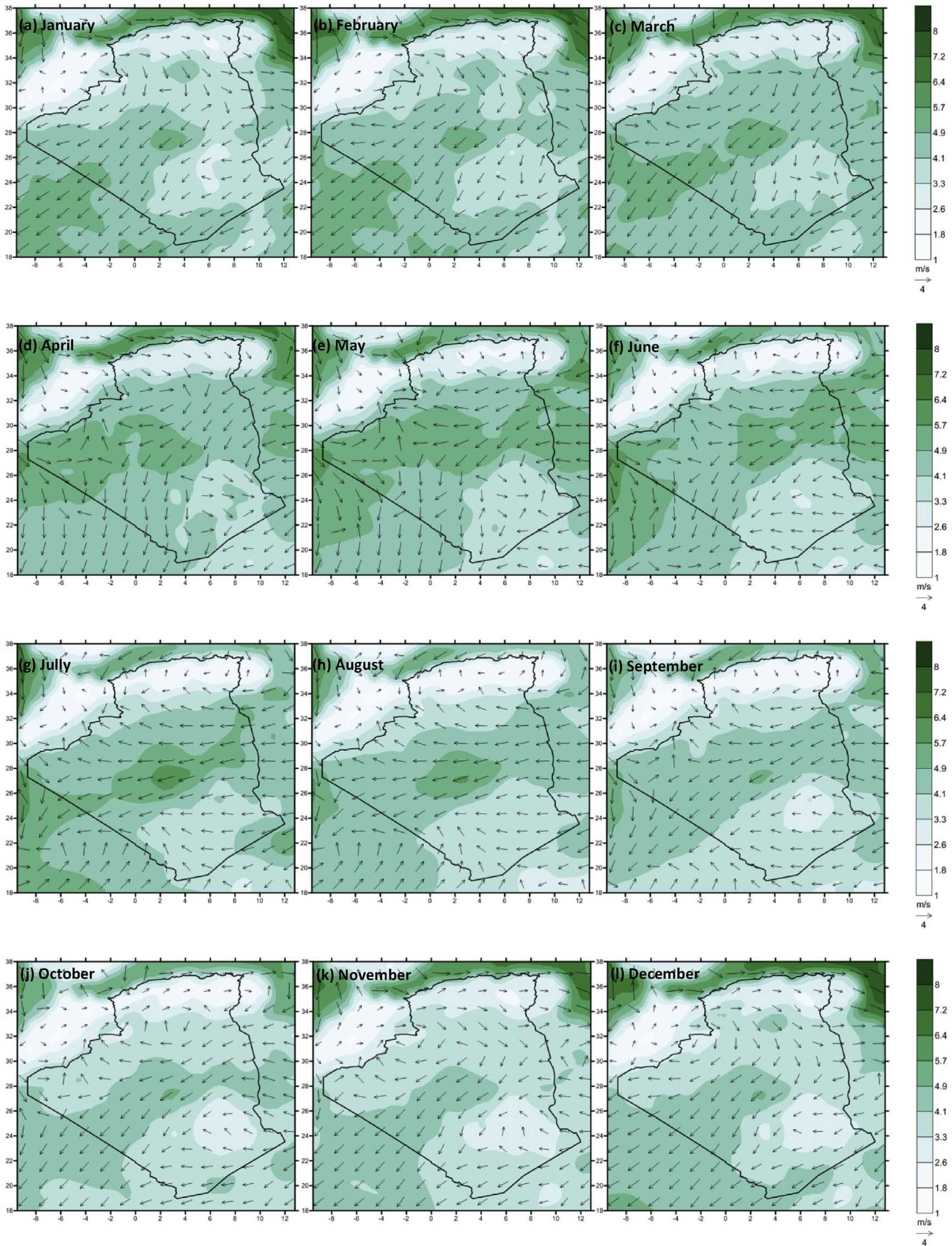

Fig. 14. Monthly means of the $10 \mathrm{~m}$ wind speed distribution over Algeria (contours), along with the prevailing wind direction (arrows), using ERA-Interim data over the period 1981-2014. 

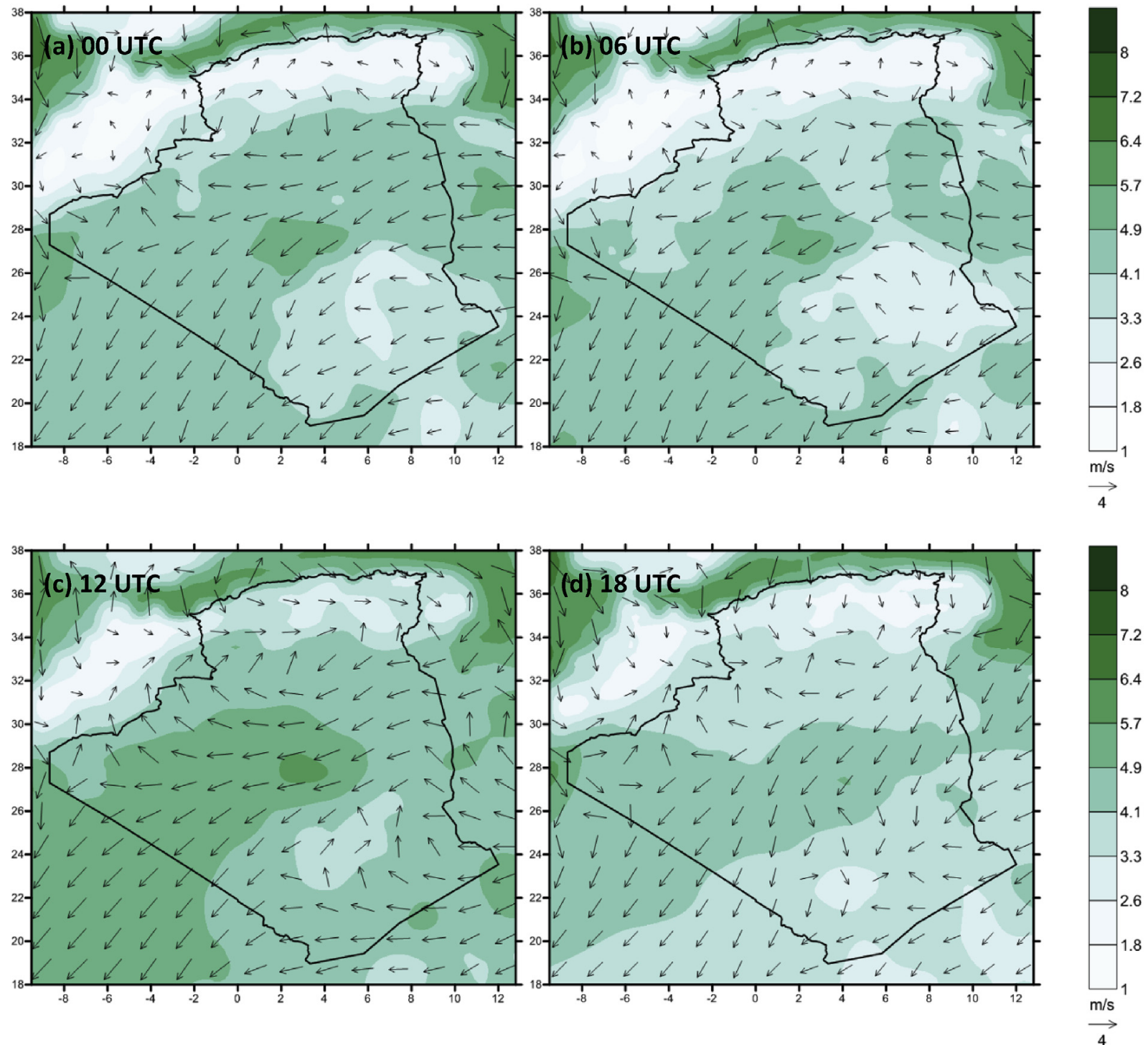

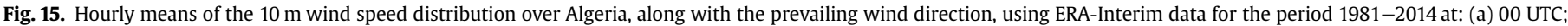
(b) 06 UTC; (c) 12 UTC and (d) 18 UTC.

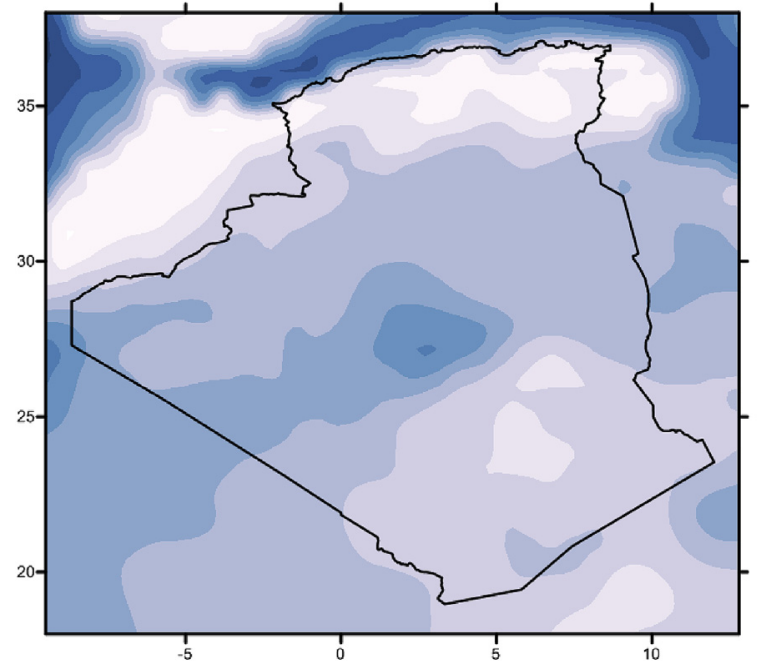

Fig. 16. The distribution of the daily wind energy potential $\left(\mathrm{MWh} \mathrm{day}^{-1}\right)$ for the Gamesa G52 wind turbine, with a rated capacity of $850 \mathrm{~kW}$ at $55 \mathrm{~m}$ a.g.l. breezes, catabatic and anabatic winds, the relatively coarse spatial resolution of the ERA-Interim reanalysis does not enable an accurate assessment of the actual wind power potential. For those cases, mesoscale and microscale models must be coupled with reanalysis so as to improve the spatial resolution of orography and to more realistically resolve the boundary layer and atmospheric turbulence effects on the wind fields. In forthcoming studies this should be foreseen for some target areas, where more accurate wind energy potential assessments are required, e.g. for planning the installation of wind farms.

Despite the limitations of the present study, it provides for the first time an assessment of the wind resource in Algeria over a relatively long time period (33 years) and on a regular grid covering the whole territory. Additionally, the mean wind and prevailing wind direction are also assessed on a sub-daily timescale, which is an innovative aspect of the present study. Since the present study confirms that most of the Algerian Sahara shows quite acceptable results for wind energy production, it is imperative to interconnect the electricity grid of the north with the south in the country to reach the $5 \mathrm{GW}$ from wind source by 2030 , already planned by the 
governmental energy plan. Moreover, although the present study includes for the first time in Algeria the use of reanalysis data in the assessment of wind energy production potential, it is important to emphase that future research will be conducted based on newly emerging products, such as the new ERA5 reanalysis dataset [52], which comprise important improvements in data quality and spatial resolution, thus allowing a verification and improvement of the present study results.

Hence, the outcomes of the present study not only contribute to a better characterization of the wind resource in Algeria, but may also assist in the selection of sites for the installation of new wind farms, envisioning an increase in the share of renewable energy to total energy production in Algeria.

\section{Acknowledgments}

This work was done through internships funding (29/CDER/STT/ 2015 and 233/CDER/STT/2016) supported by the "Centre de Développement des Energies Renouvelables" (CDER-Algeria) to the "Centre for the Research and Technology of Agro-Environmental and Biological Sciences" from the "Universidade de Trás-osMontes e Alto Douro". This work was also supported by National Funds by FCT - Portuguese Foundation for Science and Technology, under the project UID/AGR/04033/2019.

\section{References}

[1] Stambouli AB, Khiat Z, Flazi S, Kitamura Y. A review on the renewable energy development in Algeria: current perspective, energy scenario and sustainability issues. Renew Sustain Energy Rev 2012;16(7):4445-60.

[2] Diaf S, Notton G. Technical and economic analysis of large-scale wind energy conversion systems in Algeria. Renew Sustain Energy Rev 2013:19:37-51.

[3] CREG. Programme de Développement des Energies Renouvelables 2015-2030. http://www.creg.gov.dz/images/stories/PDF/creg15mars.pdf; 2015.

[4] Merzouk NK. Wind energy potential of Algeria. Renew Energy 2000;21(3-4): $553-62$.

[5] Chellali F, Khellaf A, Belouchrani A, Recioui A. A contribution in the actualization of wind map of Algeria. Renew Sustain Energy Rev 2011:15(2): 993-1002.

[6] Boudia SM, Benmansour A, Hellal MAT. Wind resource assessment in Algeria. Sustain Cities Soc 2016;22:171-83.

[7] Nedjari HD, Haddouche SK, Balehouane A, Guerri O. Optimal windy sites in Algeria: potential and perspectives. Energy 2018;147:1240-55.

[8] Kistler R, Kalnay E, Collins W, Saha S, White G, Woollen J, ..., van den Dool H. The NCEP-NCAR 50-year reanalysis: monthly means CD-ROM and documentation. Bull Am Meteorol Soc 2001;82(2):247-68.

[9] Chadee XT, Clarke RM. Large-scale wind energy potential of the Caribbean region using near-surface reanalysis data. Renew Sustain Energy Rev 2014;30: 45-58.

[10] Kubik ML, Brayshaw DJ, Coker PJ, Barlow JF. Exploring the role of reanalysis data in simulating regional wind generation variability over Northern Ireland. Renew Energy 2013;57:558-61.

[11] Cannon DJ, Brayshaw DJ, Methven J, Coker PJ, Lenaghan D. Using reanalysis data to quantify extreme wind power generation statistics: a 33 year case study in Great Britain. Renew Energy 2015;75:767-78.

[12] Schindler D, Jung C. Copula-based estimation of directional wind energy yield: a case study from Germany. Energy Convers Manag 2018;169:359-70.

[13] Chidean MI, Caamaño AJ, Ramiro-Bargueño J, Casanova-Mateo C, SalcedoSanz S. Spatio-temporal analysis of wind resource in the Iberian Peninsul with data-coupled clustering. Renew Sustain Energy Rev 2018;81:2684-94.

[14] Santos JA, Rochinha C, Liberato MLR, Reyers M, Pinto JG. Projected changes in wind energy potentials over Iberia. Renew Energy 2015;75:68-80.

[15] Elsner P. Continental-scale assessment of the African offshore wind energy potential: spatial analysis of an under-appreciated renewable energy resource. Renew Sustain Energy Rev 2019;104:394-407.

[16] Veigas M, Iglesias G. Wave and offshore wind potential for the island of Tenerife. Energy Convers Manag 2013;76:738-45.

[17] Nie B, Li J. Technical potential assessment of offshore wind energy ove shallow continent shelf along China coast. Renew Energy 2018;128:391-9.

[18] Dee DP, Uppala SM, Simmons AJ, Berrisford P, Poli P, Kobayashi S, Bechtold P. The ERA-Interim reanalysis: configuration and performance of the data assimilation system. Q J R Meteorol Soc 2011;137(656):553-97.

[19] Mattar C, Borvarán D. Offshore wind power simulation by using WRF in the central coast of Chile. Renew Energy 2016:94:22-31.
[20] Nagababu G, Bavishi D, Kachhwaha SS, Savsani V. Evaluation of wind resource in selected locations in Gujarat. Energy Procedia 2015;79:212-9.

[21] Carvalho D, Rocha A, Gómez-Gesteira M, Santos CS. Offshore wind energy resource simulation forced by different reanalyses: comparison with observed data in the Iberian Peninsula. Appl Energy 2014;134:57-64.

[22] Onea F, Deleanu L, Rusu L, Georgescu C. Evaluation of the wind energy potential along the Mediterranean Sea coasts. Energy Explor Exploit 2016;34(5): 766-92.

[23] Mattar C. Guzmán-Ibarra MC. A techno-economic assessment of offshore wind energy in Chile. Energy 2017;133:191-205.

[24] Carvalho D, Rocha A, Gómez-Gesteira M, Santos CS. WRF wind simulation and wind energy production estimates forced by different reanalyses: comparison with observed data for Portugal. Appl Energy 2014;117:116-26.

[25] Staffell I, Pfenninger S. Using a bias-corrected reanalysis to simulate current and future wind power output. Energy 2016;114:1224-39.

[26] https://apps.ecmwf.int.

[27] Jung C, Schindler D, Laible J. National and global wind resource assessment under six wind turbine installation scenarios. Energy Convers Manag 2018; $156: 403-15$

[28] Ashtine M, Bello R, Higuchi K. Assessment of wind energy potential over Ontario and Great Lakes using the NARR data: 1980-2012. Renew Sustain Energy Rev 2016;56:272-82.

[29] Elamouri M, Amar FB, Trabelsi A. Vertical characterization of the wind mode and its effect on the wind farm profitability of Sidi Daoud-Tunisia. Energy Convers Manag 2011;52(2):1539-49.

[30] Tizpar A, Satkin M, Roshan MB, Armoudli Y. Wind resource assessment and wind power potential of Mil-E Nader region in Sistan and Baluchestan Province, Iran-Part 1: annual energy estimation. Energy Convers Manag 2014;79: 273-80.

[31] Hdidouan D, Staffell I. The impact of climate change on the levelised cost of wind energy. Renew Energy 2017;101:575-92.

[32] Gualtieri G. Surface turbulence intensity as a predictor of extrapolated wind resource to the turbine hub height: method's test at a mountain site. Renew Energy 2018:120:457-67.

[33] Dahmouni AW, Salah MB, Askri F, Kerkeni C, Nasrallah SB. Assessment of wind energy potential and optimal electricity generation in Borj-Cedria, Tunisia. Renew Sustain Energy Rev 2011;15(1):815-20.

[34] Herrero-Novoa C, Pérez IA, Sánchez ML, García MÁ, Pardo N, FernándezDuque B. Wind speed description and power density in northern Spain. Energy 2017;138:967-76.

[35] Li J, Yu XB. Onshore and offshore wind energy potential assessment near Lake Erie shoreline: a spatial and temporal analysis. Energy 2018;147:1092-107.

[36] Islam MR, Saidur R, Rahim NA. Assessment of wind energy potentiality at Kudat and Labuan, Malaysia using Weibull distribution function. Energy 2011:36(2):985-92.

[37] Boudia SM, Benmansour A, Hellal MAT. Wind energy resource assessment at Tindouf region, extreme southwest of Algeria. Appl Mech Mater 2014;541: 972-6.

[38] Aries N, Boudia SM, Ounis H. Deep assessment of wind speed distribution models: a case study of four sites in Algeria. Energy Convers Manag 2018;155: 78-90.

[39] Mohammadi K, Alavi O, McGowan JG. Use of Birnbaum-Saunders distribution for estimating wind speed and wind power probability distributions: a review. Energy Convers Manag 2017;143:109-22.

[40] Embrechts P, Klüppelberg C, Mikosch T. Modelling extremal events for insurance and finance. New York: Springer; 1997.

[41] Kotz S, Nadarajah S. Extreme value distributions: theory and applications, London: Imperial College Press; 2000.

[42] Allen DJ, Tomlin AS, Bale CSE, Skea A, Vosper S, Gallani ML. A boundary layer scaling technique for estimating near-surface wind energy using numerical weather prediction and wind map data. Appl Energy 2017;208:1246-57.

[43] Gibbons JD, Chakraborti S. Nonparametric statistical inference. Springer Berlin Heidelberg; 2011. p. 977-9.

[44] Carvalho D, Rocha A, Gómez-Gesteira M, Santos CS. Potential impacts of climate change on European wind energy resource under the CMIP5 future climate projections. Renew Energy 2017:101:29-40.

[45] Whalen TM, Savage GT, Jeong GD. An evaluation of the self-determined probability-weighted moment method for estimating extreme wind speeds. J Wind Eng Ind Aerodyn 2004:92(3-4):219-39.

[46] Costoya X, deCastro M, Santos F, Sousa MC, Gómez-Gesteira M. Projections of wind energy resources in the Caribbean for the 21st century. Energy 2019;178:356-67.

[47] Boudia SM. Optimisation de l'évaluation temporelle du gisement énergétique éolien par simulation numérique et contribution à la réactualisation de l'Atlas des vents en Algérie (Doctoral dissertation). 2013.

[48] Diaf S, Notton G. Evaluation of electricity generation and energy cost of wind energy conversion systems in southern Algeria. Renew Sustain Energy Rev 2013;23:379-90.

[49] Boudia SM, Guerri O. Investigation of wind power potential at Oran, northwest of Algeria. Energy Convers Manag 2015;105:81-92.

[50] Kheder-Haddouche S, Boudia SM. Feasibility study of a wind farm in el golea region in the Algerian Sahara. In: 2018 6th international renewable and sustainable energy conference (IRSEC). IEEE; 2018, December. p. 1-6. 
[51] Boudia SM, Yakoubi A, Guerri O. Wind resource assessment in the western Part Of Algerian highlands, case study of el-bayadh. In: 2018 international conference on wind energy and applications in Algeria (ICWEAA). IEEE; 2018, November. p. $1-5$.
[52] Hersbach H. Operational global reanalysis: progress, future directions and synergies with NWP. European Centre for Medium Range Weather Forecasts; 2018. 